\title{
Erythropoietin and hypoxia increase erythropoietin receptor and nitric oxide levels in lung microvascular endothelial cells
}

\author{
Bojana B. Beleslin-Čokić ${ }^{a}$, Vladan P. Čokić ${ }^{b}$, Li Wang ${ }^{c}$, Barbora Piknova ${ }^{c}$, Ruifeng Teng ${ }^{c}$, Alan N. Schechter ${ }^{c}$, \\ Constance T. Noguchi ${ }^{\mathrm{c}, *}$
}

a Institute of Endocrinology, Diabetes and Metabolic Diseases, Clinical Center of Serbia, Dr. Subotica 13, 11000 Belgrade, Serbia

${ }^{\mathrm{b}}$ Laboratory of Experimental Hematology, Institute for Medical Research, Dr. Subotica 4, P.O. Box 102, 11129 Belgrade, Serbia

${ }^{\mathrm{c}}$ Molecular Medicine Branch, National Institute of Diabetes and Digestive and Kidney Diseases, National Institutes of Health, Building 10,

Room 9N319, 10 Center Dr., Bethesda, MD 20892-1822, USA

\section{A R T I C L E I N F O}

Article history:

Received 20 May 2010

Received in revised form 22 December 2010

Accepted 20 January 2011

Available online 15 February 2011

\section{Keywords:}

Erythropoietin

Erythropoietin receptor

NO

Hypoxia

HMVEC-L

\begin{abstract}
A B S T R A C T
Acute lung exposure to low oxygen results in pulmonary vasoconstriction and redistribution of blood flow. We used human microvascular endothelial cells from lung (HMVEC-L) to study the acute response to oxygen stress. We observed that hypoxia and erythropoietin (EPO) increased erythropoietin receptor (EPOR) gene expression and protein level in HMVEC-L. In addition, EPO dose- and time-dependently stimulated nitric oxide (NO) production. This NO stimulation was evident despite hypoxia induced reduction of endothelial NO synthase (eNOS) gene expression. Western blot of phospho-eNOS (serine1177) and eNOS and was significantly induced by hypoxia but not after EPO treatment. However, iNOS increased at hypoxia and with EPO stimulation compared to normal oxygen tension. In accordance with our previous results of NO induction by EPO at low oxygen tension in human umbilical vein endothelial cells and bone marrow endothelial cells, these results provide further evidence in HMVEC-L for EPO regulation of NO production to modify the effects of hypoxia and cause compensatory vasoconstriction.
\end{abstract}

(c) 2011 Elsevier Ltd. All rights reserved.

\section{Introduction}

Erythropoietin (EPO) is a hypoxia-inducible cytokine required for production of mature erythrocytes. EPO acts by binding to and inducing expression of the erythropoietin receptor (EPOR). Beyond erythropoiesis, EPO and EPOR elicit response in numerous tissues, particularly in endothelial cells $[1,2]$. The ability for EPO to stimulate cell proliferation and chemotaxis in endothelial cells was first demonstrated in vitro and then in vivo in the chick chorioallantoic membrane and mouse uterine endometrium $[3,4]$. The pleiotrophic nature of EPO proliferative and survival response is observed in a variety of non-hematopoietic cells including tumor cells $[5,6]$. Moreover, EPO in combination with low oxygen tension can increase the endothelial capacity to produce nitric oxide (NO) by induction of both EPOR and endothelial nitric oxide synthase (eNOS) [7]. EPO activation of NO production in murine erythrocytes has also been reported [8]. EPO stimulated production of NO may compensate for the enhanced NO scavenging in the presence of cell-free hemoglobin followed by haptoglobin binding to

\footnotetext{
* Corresponding author. Address: Molecular Cell Biology Branch, National Institute of Diabetes and Digestive and Kidney Diseases, Building 10, Room 9N319, 10 Center Dr. MSC-1822, Bethesda, MD 20892-1822, USA. Tel.: +1 301 496 1163; fax: +1 3014020101.

E-mail address: cnoguchi@helix.nih.gov (C.T. Noguchi).
}

facilitate clearance, especially with reduced oxygen availability $[9,10]$. Additionally, EPO induced neovascularisation through endothelial progenitor cells recruitment from the bone marrow associated with coronary heart disease and possibly acting in conjunction with stimulated VEGF production by cardiomyocytes $[11,12]$. Several in vivo studies demonstrated an EPO protective effect to endothelial cells in diverse models of vascular disease $[13,14]$.

Endothelial cells exhibited specific responses in adaptation to low oxygen tension in lung [15]. Acute exposure to hypoxia resulted in vasoconstriction of pulmonary arteries, increased pulmonary arterial pressure and redistribution of blood flow from basal to the apical level of lung. In chronic hypoxic lung disease dysfunction of mechanisms regulating vascular tone and remodeling of the pulmonary vasculature contribute to the development of sustained pulmonary hypertension [16]. Chronic hypoxia stimulated polycytemia results in increased blood viscosity and pulmonary hypertension.

NO has a central role in modulation of pulmonary vascular tone. Three isoforms of the enzyme responsible for the NO production are endothelial, inducible (iNOS) and neuronal (nNOS) $[17,18]$. All three isoforms are increased in chronic hypoxic pulmonary hypertension [19]. eNOS and nNOS are constitutively expressed NOS isoforms and require calcium for activation, while iNOS is calcium independent but inducible by cytokines. In the normal 
murine pulmonary circulation nNOS does not modulate tone, whereas eNOS-derived NO is the principle mediator of endothelium-dependent vasodilation in the pulmonary circulation, and both eNOS and iNOS play a role in modulating basal tone chronically [20]. eNOS is the principal isoform expressed in the normal pulmonary vasculature [21].

To clarify the response of lung endothelial cells to EPO stimulation, we examined the levels of EPOR and eNOS/iNOS expression in cultured endothelial cells at normoxia and low oxygen tension. We found that EPO increased expression of EPOR, particularly at low oxygen tension. EPO had little effect on NO production at normoxia. At hypoxia, concomitant with the increase in EPOR expression, EPO increased production of NO up to $4 \mathrm{~h}$. This EPO induction of NO was NOS dependent and evident despite hypoxia induced down regulation of eNOS mRNA and protein expression. The activity of eNOS is regulated primarily by post-translational mechanisms including phosphorylation at multiple sites, but one of the most studied sites is the activation of serine 1177 . However, ratio for phosphorylated eNOS at serine 1177 and eNOS, showed increased in there activity at low oxygen but not after EPO stimulation. In contrast, Western blotting showed that iNOS increased at low oxygen tension and even further when combined with EPO treatment. These data suggest that the low level of NO induced at low oxygen tension by EPO stimulation in lung endothelial cells is NOS dependent and concomitant with increase in the low level of iNOS protein expression but decrease in eNOS activity.

\section{Materials and methods}

\subsection{HMVEC-L cell culture}

Human microvascular endothelial cells from lung (HMVEC-L; Clonetics Endothelial Cell System, Lonza, Walkersville, MD) were cultured in endothelial basal media (EGM-2MV) containing 5\% FBS and cytokines under $5 \% \mathrm{CO}_{2}$ with balanced $95 \%$ room air. Before exposure to $2 \%$ oxygen, cells were washed in HEPES buffer ( $N$-2-hydroxyethylpiperazine- $N^{\prime}$-2-ethanesulfonic acid) and plated in EBM-2 containing 1\% FBS and cytokines. Incubator (Forma Scientific, Marietta, $\mathrm{OH}$ ) with low oxygen control capability was used to generate reduced oxygen tension.

\subsection{Real-time quantitative RT-PCR}

At third passage, HMVEC-L were plated at cell density of 3000 cells in $35 \mathrm{~mm}$ culture dishes at normal and reduced oxygen tensions with and without EPO $(5 \mathrm{U} / \mathrm{ml})$. After two days, the cells were harvested, RNA was isolated using STAT 60 (Tel-TEST, Friendswood, TX) and treated with RNase-Free DNase (Promega, Madison, WT). Total RNA ( $1 \mu \mathrm{g}$ ) of each sample was used for cDNA synthesis using murine leukemia virus (MuLV) reverse transcriptase (RT) and oligo $d(T)_{16}$ (Applied Biosystems, Foster City, CA). Quantitative real-time RT-PCR analysis was performed using the ABI PRISM 7700 Detection System (Applied Biosystems). The conditions and Taqman oligonucleotide probes (Applied Biosystems) were used as previously described [7]. Beta-actin was used as an internal control for the total amount of RNA analyzed.

\subsection{Protein analysis}

HMVEC-L cells were plated in EBM-2 media with and without $5 \mathrm{U} / \mathrm{ml} \mathrm{EPO}$. After $48 \mathrm{~h}$, cells were washed with HEPES buffer, treated with lysis buffer and detached from the plate. The cell lysate was centrifuged for $10 \mathrm{~min}$ and the supernatant was transferred to a new tube. For EPOR analysis, $1 \mathrm{mg}$ of protein was incubated with EPOR antibody (Santa Cruz Biotechnology, Santa Cruz, CA) overnight. The complex was captured with protein A-Agarose (Santa Cruz Biotechnology) for $2 \mathrm{~h}$ at $4{ }^{\circ} \mathrm{C}$, washed two times and incubated at $70^{\circ} \mathrm{C}$ for $10 \mathrm{~min}$. The proteins were separated by sodium dodecyl sulfate polyacrylamide gel electrophoresis (SDS-PAGE) and transferred to a nitrocellulose membrane. The membrane was blocked with $5 \%$ milk with $0.1 \%$ Tween 20 for $1 \mathrm{~h}$ at room air and probed with primary antibody specific for EPOR antibody (Santa Cruz Biotechnology), 1:1000 at $4{ }^{\circ} \mathrm{C}$ overnight. Hyperfilm was developed to visualize the secondary antibody by enhanced chemiluminescence (ECL; Amersham Pharmacia Biotech, Piscataway, NJ). For Western blotting using anti-eNOS (BD Transduction Laboratories, San Jose, CA), anti-phospho-eNOS (Ser1177), and anti-iNOS (Cell Signaling Technology, Inc.) antibodies, HMVEC-L were treated with EPO $(5 \mathrm{U} / \mathrm{ml})$ for $48 \mathrm{~h}$. Cells were washed with HEPES, treated with lysis buffer and scraped from the plate. The proteins were separated by SDS-PAGE and transferred to a nitrocellulose membrane, blocked with primary antibody overnight at $4{ }^{\circ} \mathrm{C}$ and visualized by chemiluminescence. The membrane was stripped for $1 \mathrm{~h}$, washed, blocked and incubated with the $\beta$-actin antibody (Sigma, St. Louis, MO) overnight at $4{ }^{\circ} \mathrm{C}$ and then visualized. The Java image-processing program inspired by $\mathrm{NIH}$ image was used for quantitative analysis.

\subsection{Ozone-based chemiluminescent determination of nitrite/nitrate in supernatant of cell culture}

For only nitrite measurement, confluent HMVEC-L in 6-well plates were washed once with HEPES buffer (BioWhittaker Inc.) and EBM-2 was added (total volume $2 \mathrm{ml}$ ). HMVEC-L were pretreated for $30 \mathrm{~min}$ with $1 \mathrm{mM} \mathrm{L-N}{ }^{\mathrm{G}}$-Nitro-arginine-methyl ester (L-NAME, Alexis Biochemicals). The cells were exposed to EPO (1, $5,10 \mathrm{U} / \mathrm{ml}$ ) in the presence of L-arginine (Sigma-Aldrich, St. Louis, MO). After incubation period, the supernatants of treated cells were injected in reductants in line with the Sievers Model 280 NO analyser (Sievers, Boulder, CO). NO was measured by nitrite reduction in acidified $\mathrm{KI}: 7 \mathrm{ml}$ of glacial acetic acid, $2 \mathrm{ml}$ of distilled water, $50 \mathrm{mg}$ of $\mathrm{KI}$, a crystal of iodine was added to yield a concentration of 6 to $20 \mathrm{mmol} / 1$ (Sigma-Aldrich). Helium was bubbled through the reaction mixture. For combined nitrite/nitrate measurement, confluent HMVEC-L in small flasks were washed once with HEPES buffer and EBM-2 was added (total volume $5 \mathrm{ml}$ ). After EPO treatment $(5 \mathrm{U} / \mathrm{ml})$ and $4 \mathrm{~h}$ of incubation, nitrite levels were measured as previously described, whereas nitrate levels were measured using vanadium (III) chloride in hydrochloric acid at $90{ }^{\circ} \mathrm{C}$ with the Sievers Model 280 NO analyser.

\subsection{Statistical analysis}

The one way analysis of variance (ANOVA) and Dunnett's post tests were applied using Prism 4 software (GraphPad Software Inc., San Diego, CA).

\section{Results}

\subsection{EPOR expression in HMVEC-L}

Our previous results on EPO activity in endothelial cells indicated that the optimal concentration of EPO stimulation of EPOR expression is $5 \mathrm{U} / \mathrm{ml}$ [7]. To investigate EPOR expression in HMVEC-L, cells were exposed to normal $\left(21 \% \mathrm{O}_{2}\right)$ and low $(2 \%$ $\mathrm{O}_{2}$ ) oxygen tension for $48 \mathrm{~h}$. We observed that EPO $(5 \mathrm{U} / \mathrm{ml})$ induced EPOR mRNA in lung endothelial cells at normal oxygen tension (Fig. 1A). The increase of EPOR mRNA was also observed at $2 \%$ $\mathrm{O}_{2}(P<0.01)$ and adding EPO to the culture media further doubled EPOR expression (Fig. 1A). Western blotting showed that EPO 
treatment of HMVEC-L, under hypoxic condition, induced the EPOR protein more than 3 -fold compared to cultures at $21 \% \mathrm{O}_{2}$ with and without EPO (Fig. 1B). Therefore, while EPO had no effect on EPOR protein level at normoxia, quantification of the EPOR bands from Western blotting (Fig. 1C) showed significant EPOR induction after EPO stimulation at low oxygen tension $(P<0.01)$. EpoR appeared to increase with hypoxia, but this increase is not significant. These results demonstrated stimulative effects of EPO and hypoxia on total EPOR levels in HMVEC-L.

\subsection{NO production in HMVEC-L}

We previously found that EPO stimulated NO production in selected endothelial cells through eNOS activation that was reflected in increased eNOS expression and phosphorylation [7]. HMVEC-L were treated with different concentrations of EPO $(1,5$ and $10 \mathrm{U} /$ $\mathrm{ml}$ ) at $21 \%$ and $2 \%$ oxygen. The NO production after EPO stimulation was measured at $30 \mathrm{~min}$ (Fig. 2), $1 \mathrm{~h}$ (Fig. 3) and $4 \mathrm{~h}$ (Fig. 4). EPO did not induce statistically significant changes in NO produc-
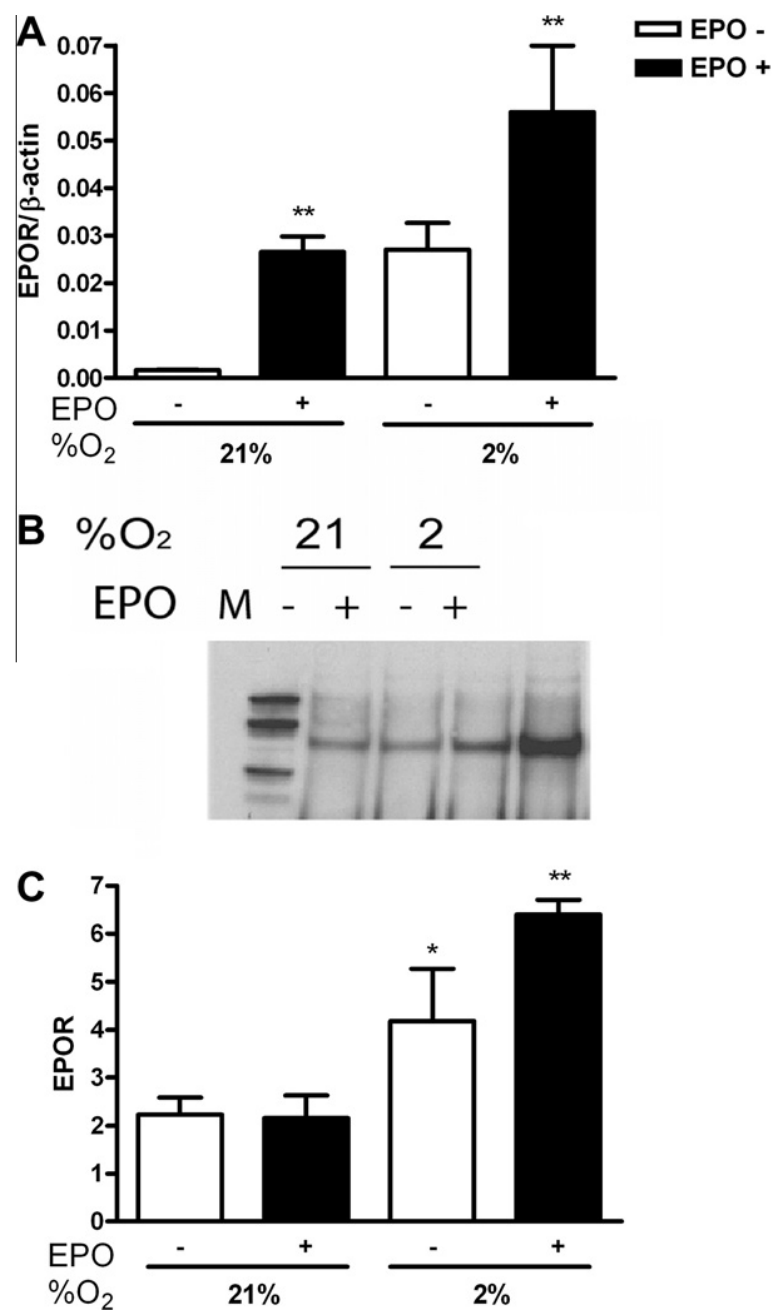

Fig. 1. Induction of EPOR by hypoxia and EPO in HMVEC-L. (A) EPOR expression was determined by quantitative real-time PCR at $21 \%$ and $2 \% \mathrm{O}_{2}$, with (black bars) and without (open bars) EPO $(5 \mathrm{U} / \mathrm{ml})$ treatment. EPOR gene expression was induced with EPO after $48 \mathrm{~h}$ at $21 \%$ and $2 \% \mathrm{O}_{2}$. Results were normalized to $\beta$-actin expression. Values are means $\pm \operatorname{SEM}(n=3) .{ }^{* *} P<0.01$ compared to nontreated cells (B) EPOR protein induction by EPO in normoxia vs. hypoxia as measured by Western blotting. (C) Quantification of EPOR Western blotting showed significant induction up to 3 -fold at $2 \% \mathrm{O}_{2}$ after EPO treatment. Open bars demonstrate $21 \%$ and $2 \%$ of oxygen and black bars cells treated with EPO. Values are means \pm SEM $(n=3)$. ${ }^{* *} P<0.01$ compared to samples under normoxia. tion at $21 \%$ oxygen at all time points (Figs. 2B, 3B and 4). L-NAME treatment in combination with EPO decreased NO production compared with EPO alone.

HMVEC-L cultured at $2 \%$ oxygen exhibited a greater response to EPO, consistent with the up regulation of EPOR expression (Fig. 1). The optimum for NO production was observed with $5 \mathrm{U} / \mathrm{ml}$ of EPO at $30 \mathrm{~min}, 1 \mathrm{~h}$ and $4 \mathrm{~h}$ (Figs. 2A, 3A and 4). NO induction increased with time and appeared greatest after $4 \mathrm{~h}$. Addition of NOS inhibitor L-NAME, decreased the EPO induction of NO at all three time points at $2 \%$ oxygen.

\subsection{Nitrite and nitrate production in HMVEC-L}

Endothelial NO synthesis is important in controlling vascular tone and blood pressure [22]. Under normal physiological conditions, nitrite, along with NO and nitrate, is part of a complex biological cycle in mammals [23]. NO itself is short-lived, as it is rapidly oxidized to nitrite in aqueous solutions, and directly oxidized to nitrate in the presence of superoxide or oxyhemoglobin [24]. Inorganic nitrate synthesis results from NO oxidation and may be an important storage form of reactive nitrogen oxides, which can be reduced back to nitrite and then NO under certain physiological and pathological conditions [23]. In HMVEC-L released NO was monitored using nitrate and nitrite levels as an index of NO production.

After $4 \mathrm{~h}$ of HMVEC-L stimulation by EPO $(5 \mathrm{U} / \mathrm{ml})$ nitrite levels were significantly induced at low oxygen tension (Fig. 5A). There was about the same production of nitrite in HMVEC-L cultured at $21 \%$ and $2 \%$ of oxygen. However, overall nitrate production in cells was as expected higher in comparison to nitrite levels and significantly stimulated by hypoxya itself (Fig. 5B). EPO remarkably stimulated nitrate production both at normal and low oxygen tension (Fig. 5B), suggesting that nitrite rapidly converts to nitrate.
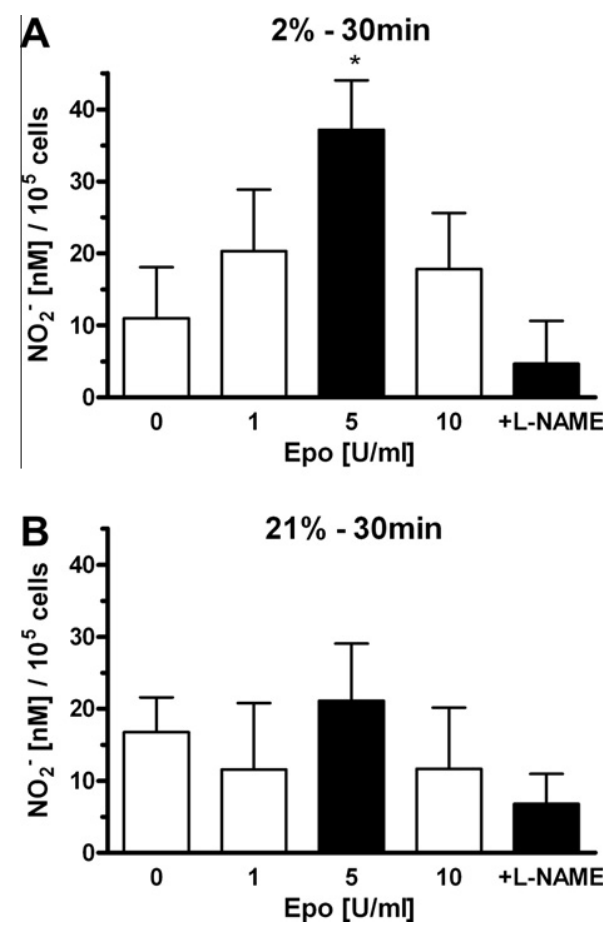

Fig. 2. Effects of EPO on nitrite production in HMVEC-L at hypoxic and normoxic condition at $30 \mathrm{~min}$. Effects of 1,5 and $10 \mathrm{U} / \mathrm{ml}$ of EPO stimulation on $\mathrm{NO}_{2}$ production after $30 \mathrm{~min}$ were determined at $2 \% \mathrm{O}_{2}(\mathrm{~A})$ and $21 \%$ oxygen (B). The effect of EPO treatment at $5 \mathrm{U} / \mathrm{ml}$ on $\mathrm{NO}_{2}{ }^{-}$production is shown as a shaded bar. NO production was measured as released nitrite in the supernatant per $10^{5}$ cells. $1 \mathrm{mM}$ L-NAME was added in the presence of $5 \mathrm{U} / \mathrm{ml}$ of EPO. Values are means \pm SEM $(n=3) .{ }^{*} P<0.05$ compared to control and L-NAME treatment. 

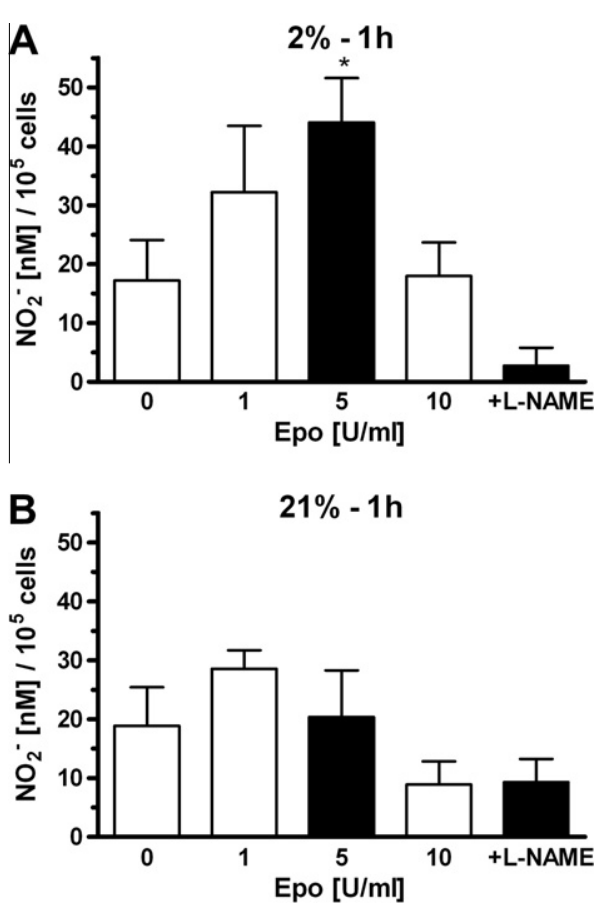

Fig. 3. Effects of EPO on nitrite production in HMVEC-L at hypoxic and normoxic condition at $1 \mathrm{~h}$. Cells were treated with 1,5 and $10 \mathrm{U} / \mathrm{ml}$ of EPO on $\mathrm{NO}_{2}$ production after $1 \mathrm{~h}$ were determined at $2 \%$ (A) and $21 \%$ oxygen (B). Shaded bar with $5 \mathrm{U} / \mathrm{ml}$ of EPO represents the optimum effect on $\mathrm{NO}_{2}^{-}$production. NO production was measured as released nitrite in the supernatant per $10^{5}$ cells. $1 \mathrm{mM}$ L-NAME suppressed NO induction stimulated by $5 \mathrm{U} / \mathrm{ml}$ of EPO. Values are means $\pm \operatorname{SEM}(n=3) .{ }^{*} P<0.05$ compared to control and L-NAME treatment.
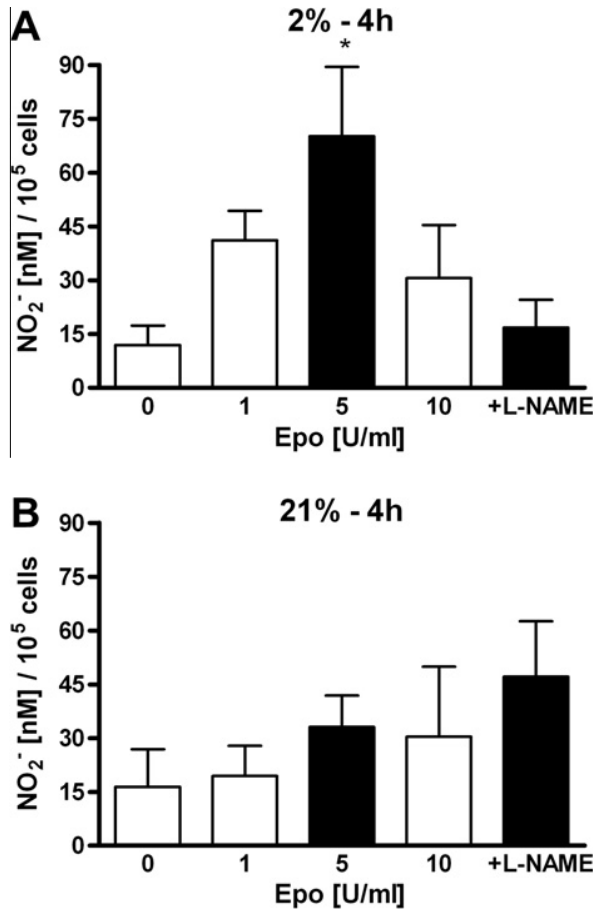

Fig. 4. Effects of EPO on nitrite production in HMVEC-L at hypoxic and normoxic condition at $4 \mathrm{~h}$. Cells were treated with 1,5 and $10 \mathrm{U} / \mathrm{ml}$ of EPO on $\mathrm{NO}_{2}$ production after $4 \mathrm{~h}$ were determined at $2 \%(\mathrm{~A})$ and $21 \%$ oxygen (B). Shaded bar with $5 \mathrm{U} / \mathrm{ml}$ of EPO represents the optimum effect on $\mathrm{NO}_{2}^{-}$production. NO production was measured as released nitrite in the supernatant per $10^{5}$ cells. One millimolar L-NAME suppressed NO induction stimulated by $5 \mathrm{U} / \mathrm{ml}$ of EPO. Values are means \pm SEM $(n=3) .{ }^{*} P<0.05$ compared to control and L-NAME treatment.
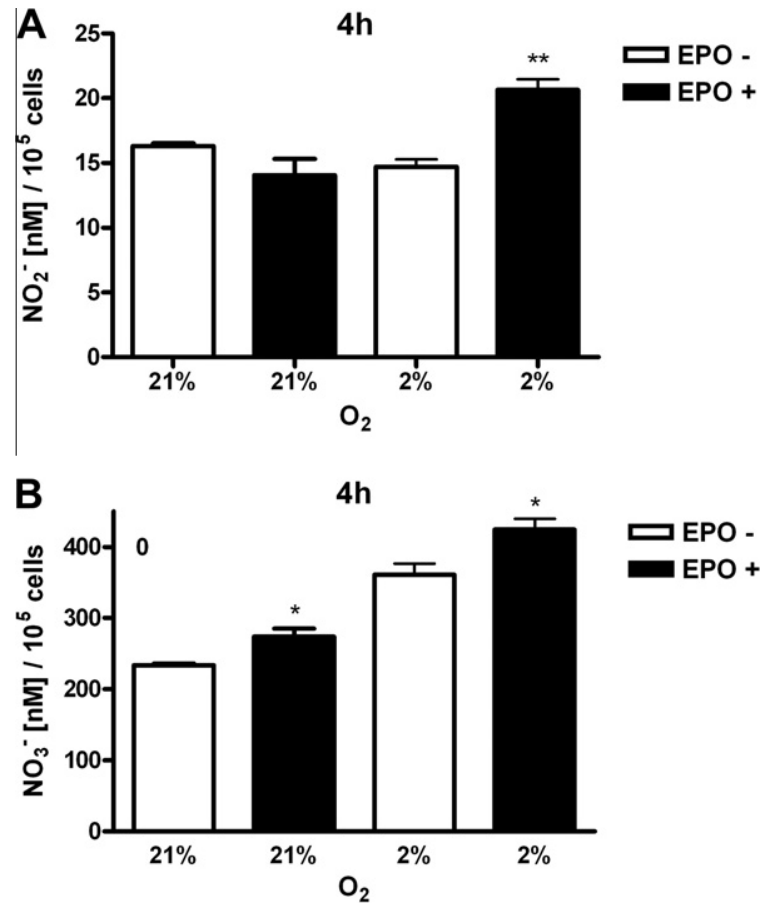

Fig. 5. Production of nitrite and nitrate in HMVEC-L. Cells were cultured at $21 \%$ and $2 \%$ oxygen with (black bars) and without (open bars) $5 \mathrm{U} / \mathrm{ml}$ of EPO for $4 \mathrm{~h}$. (A) Nitrite levels $\left(\mathrm{NO}_{2}{ }^{-}\right)$showed the induction after EPO stimulation at $2 \%$ oxygen. (B) Nitrate levels $\left(\mathrm{NO}_{3}{ }^{-}\right)$were induced with EPO at normal and low oxygen tension. Values are means \pm SEM $(n=3)$. ${ }^{*} P<0.05$ compared to at normoxia. ${ }^{* *} P<0.01$ compared to cells at normoxia.

\section{4. eNOS, phosphoNOS and iNOS expression in HMVEC-L}

The three known isoforms of NOS were identified in the lung, two constitutive NOS isoforms are neuronal (nNOS) and endothelial (eNOS), they are regulated by calcium and calmodulin ions and release NO in small (nanomolar) quantities. However, this quite limited NO production by constitutive NOS are sufficient to keep the extremely vasodilated baseline systemic vascular tone stable, inhibit the interaction of leukocytes with the endothelium, inhibit platelet aggregation and control cell proliferation [25]. The third isoform of NOS is inducible iNOS isoform, independent of calcium and calmodulin ions, which promotes the release of greater (micromolar) amounts of NO. It is known that iNOS isoform can be induced by inflammatory stimuli [26].

Expression of eNOS and iNOS were examined in HMVEC-L. Cells were cultured with and without EPO for $48 \mathrm{~h}$ and we found that expression of eNOS mRNA was significantly decreased at $2 \%$ oxygen $(P<0.01$, Fig. $6 A)$. This change in eNOS expression is analogous to the 2 - to 4 -fold decrease we previously observed in primary endothelial cells from human umbilical vein (HUVEC) and artery (HUAEC) when cells were cultured at reduced oxygen tension [7]. Adding EPO $(5 \mathrm{U} / \mathrm{ml})$ did not affect expression of eNOS mRNA in HMVEC-L (data not shown). Western blotting of eNOS showed that expression was reduced up to 2 -fold at $2 \% \mathrm{O}_{2}$. Moreover, antibody specific for eNOS phosphorylated at serine 1177 followed the decrease in protein and mRNA expression of eNOS (Fig. 6B and C). However, when we examined the ratio phospho eNOS to eNOS we found statistically significant changes in expression but only at low oxygen (Fig. 6D). The reduction of eNOS expression at the mRNA and protein levels by hypoxia, not significantly reversed by EPO treatment, may account for the relatively low EPO induction of NO production in HMVEC-L in comparison to HUVEC or HUAEC where NO production was an order of magnitude greater following EPO treatment [7]. Interestingly, iNOS protein was 

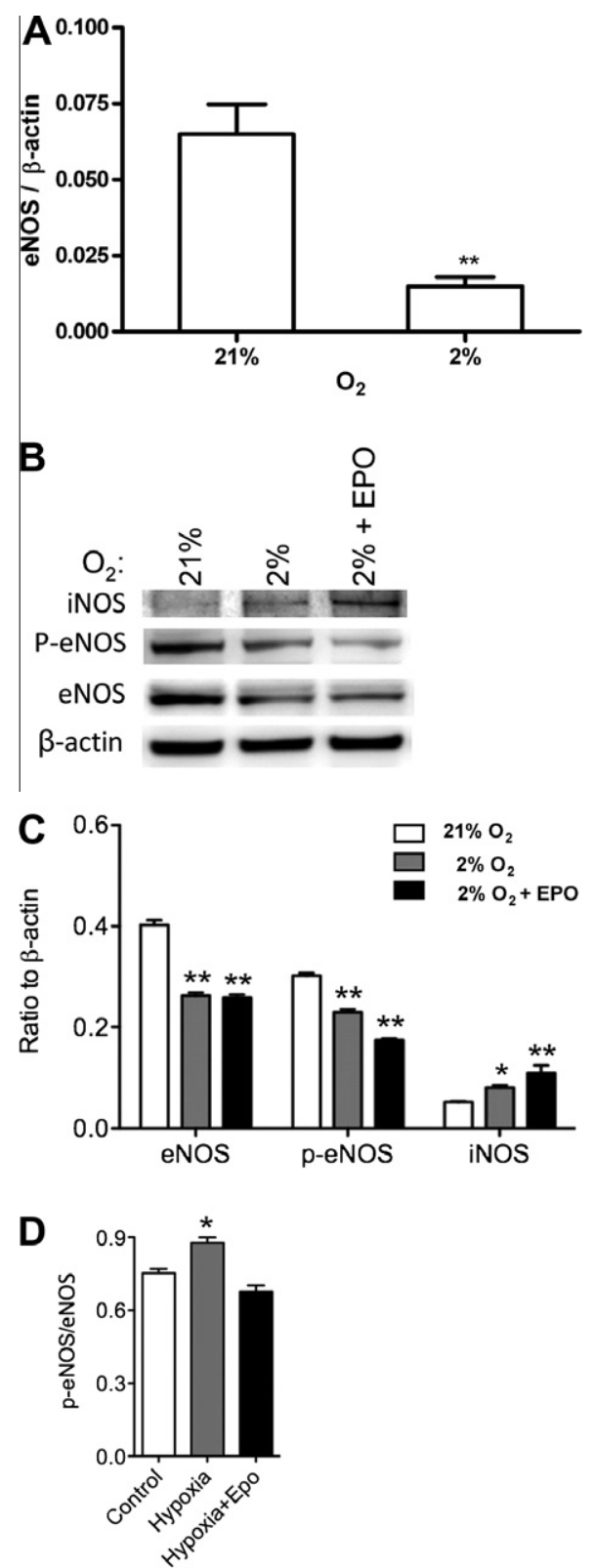

Fig. 6. eNOS, p-eNOS, iNOS expression in HMVEC-L. (A) eNOS expression was determined by quantitative real-time RT-PCR at $21 \%$ and $2 \% \mathrm{O}_{2}$. There was a significant decrease of eNOS expression at $2 \% \mathrm{O}_{2}$. Results were normalized to $\beta$ actin expression. Values are means $\pm \operatorname{SEM}(n=3) .{ }^{* *} P<0.01$ compared to cells at normoxia. (B) Western blotting analysis confirmed the decreased expression of eNOS and p-eNOS at $2 \% \mathrm{O}_{2}$ that persisted with EPO stimulation. iNOS expression was induced at $2 \%$ oxygen and even more with $5 \mathrm{U} / \mathrm{ml}$ of EPO. (C) Quantification of eNOS, p-eNOS and iNOS in relation to $\beta$-actin. (D) Quantification of p-eNOS/eNOS ratio from Western blotting. ${ }^{*} P<0.05$ compared to at normoxia. ${ }^{* *} P<0.01$ compared to cells at normoxia.

induced by hypoxia and even more in combination with EPO stimulation. These data suggest that small amounts of NO produced in HMVEC-L under low oxygen tension could be accompanied with induction of iNOS protein with hypoxia and more with EPO, but not eNOS in lung microvascular cells.

\section{Discussion}

Hypoxia increased EPOR mRNA and protein levels in HMVEC-L that are further induced by EPO particularly at low oxygen ten- sion. Induction of EPOR mRNA by EPO is regulated in part through activation of GATA transcription factors as observed in erythroid, myoblast and neuronal cells [27-29]. In addition, EPOR reporter gene assays show a direct response of EPOR promoter activity to reduced oxygen tension as well as increased NO production in neuronal cells [30], providing insight on the induction of EPOR expression by EPO and hypoxia. Hypoxia reduced eNOS mRNA and protein levels at $2 \% \mathrm{O}_{2}$. This change in phospho-eNOS/eNOS is small and reduction in eNOS protein is considerably larger so that is very likely that there is an overall reduction in eNOS activity. EPO stimulated NO production in HMVEC-L at low oxygen tension, although the level of NO production was markedly lower than the level of EPO-induced NO in HUVEC reflecting the overall reduction of eNOS by hypoxia [7]. EPO stimulated nitrite and even more nitrate production at normal and low oxygen tension, suggesting that nitrite rapidly converts to nitrate. In contrast to eNOS, iNOS was induced with low oxygen and EPO stimulation. Compared with previous reports of EPO stimulation of endothelial NO production, these data indicate variation in endothelial response in EPO-induced NO at hypoxia consistent with endothelial cell diversity in tissue specific response.

The pulmonary endothelium is important for the maintenance of the blood flow in the pulmonary vasculature. When the lungs are exposed to low oxygen, pulmonary arteries exhibit vasoconstriction and redistribution of blood flow [15]. Chronic hypoxia decreases the luminal diameter of the small pulmonary arteries and increases vascular resistance, contributing to the development of hypertension [31]. Also, chronic hypoxia stimulates production of erythrocytes and polycythemia, resulting in increased blood viscosity and can contribute to pulmonary hypertension [32]. Beyond excessive erythrocytosis and/or polycythemia, a variety of other factors have been implicated in the mechanisms of pulmonary hypertension such as hypoxia, vascular remodeling and NO. In transgenic mice with constitutively overexpressed human EPO gene, pulmonary artery pressure was increased in vivo but was reduced in blood-free perfused lungs [33]. These mice have polycythemia but normal blood pressure, heart rate and cardiac output and in pulmonary vasculature elevated prostacyclin production, eNOS expression and reduced vascular smooth muscle thickness. Since these mice have elevated pulmonary hypertension in vivo but not in vitro, it suggests that their pulmonary hypertension is due to the increased blood viscosity. With respect to tissue hypoxia, our results showed that eNOS expression was decreased when HMVEC-L were exposed to $2 \%$ $\mathrm{O}_{2}$ for $48 \mathrm{~h}$, suggesting that the long incubation and low oxygen tension dramatically changed eNOS expression locally in the pulmonary tissue. Stimulation with $5 \mathrm{U} / \mathrm{ml}$ of EPO did not reverse the decreased eNOS expression, in contrast to EPO induction of eNOS in HUVEC [7]. The iNOS isoform can be induced by inflammatory stimuli [26]. Recent evidence has revealed that NO production is increased in lung diseases accompanied by intense inflammation, such as acute respiratory distress syndrome (ARDS) and that NO derived from iNOS might aggravate such diseases [34]. It has been observed that patients with ARDS present elevated lung concentrations of NO metabolites (nitrite and nitrate) and 3-nitrotyrosine [35]. Because of this findings it is proposed that selective iNOS inhibition can have beneficial effects in the treatment of lung diseases accompanied by inflammation and pulmonary arterial hypertension, but not yet clinically validated. In case of HMVEC-L the level of iNOS was low compare to eNOS. But after $48 \mathrm{~h}$ iNOS protein increased as oxygen decreased to $2 \%$ and further more after EPO stimulation. Of note, the amount of iNOS protein is only one of several factors that regulate iNOS generated NO production [36]. However, these data suggest that acute exposure of HMVEC-L to low oxygen may produce NO via a mechanism independent of eNOS activation, but is insufficient to 
protect cells form hypoxic stress, and consequently leads to vasoconstriction.

The differential response of various endothelial beds to EPO may explain in part the role of EPO in modulating endothelial response related to the pulmonary vasculature. Several reports suggest that EPO may serves as a cytokine that elicits mobilization of endothelial progenitor cells promoting the repair process of the injured pulmonary endothelium [14]. EPOR-null mutant mice expressing EPOR exclusively in the erythroid lineage (EPOR ${ }^{-1-}$ rescued mice) showed accelerated pulmonary hypertension and pulmonary vascular remodeling, illustrating the importance of EPO and EPOR for pulmonary endothelial function [14]. Our data suggest that primary endothelial cells from lung after stimulation with EPO at low oxygen tension induced EPOR and increased NO production, but did not significantly affect the inhibition of eNOS expression, while iNOS began to induce within $48 \mathrm{~h}$. In EPOR ${ }^{-1-}$ rescued mice, when bone-marrow derived endothelial progenitor cells were intravenously infused, incorporation of endothelial cells was significantly impaired comparing to wild type animals, again suggesting the significance EPO and EPOR in endothelial cells. In wild-type mice after three weeks exposure to $10 \%$ oxygen, endothelial cells were incorporated into the pulmonary endothelium and EPOR and eNOS were induced [14]. On the other hand, NO is also a reactive radical capable of tissue injury either directly or after reacting with other radicals. There is evidence that when rats are exposed to $10 \%$ oxygen, NO production is increased during the first days of hypoxia, mostly by the iNOS isoform [36]. It was suggested that transient iNOS induction in the pulmonary vascular wall at the beginning of chronic hypoxia participates later in the pathogenesis of pulmonary hypertension [37]. Our data also suggest that after $48 \mathrm{~h}$ of exposure to $2 \%$ oxygen, there was an increase in iNOS protein that increased further with EPO treatment.

Taken together, our data suggest that the increase of plasma EPO level in response to oxygen stress results in upregulated EPOR in lung endothelial cells accompanied by the NOS dependent small induction of NO that may be insufficient to counteract hypoxic vasoconstriction.

\section{Acknowledgments}

This research was supported by the Intramural Research Program of the National Institute of Diabetes and Digestive and Kidney Diseases and by a grant from the Serbian Ministry of Science and Technological Development [175053].

\section{References}

[1] Anagnostou A, Lee ES, Kessimian N, Levinson R, Steiner M. Erythropoietin has a mitogenic and positive chemotactic effect on endothelial cells. Proc Natl Acad Sci USA 1990;87(15):5978-82.

[2] Anagnostou A, Liu Z, Steiner M, Chin K, Lee ES, Kessimian N, et al. Erythropoietin receptor mRNA expression in human endothelial cells. Proc Natl Acad Sci USA 1994;91(9):3974-8.

[3] Crivellato E, Nico B, Vacca A, Djonov V, Presta M, Ribatti D. Recombinant human erythropoietin induces intussusceptive microvascular growth in vivo. Leukemia 2004;18(2):331-6.

[4] Yasuda Y, Masuda S, Chikuma M, Inoue K, Nagao M, Sasaki R. Estrogendependent production of erythropoietin in uterus and its implication in uterine angiogenesis. J Biol Chem 1998;273(39):25381-7.

[5] Jeong JY, Hoxhaj G, Socha AL, Sytkowski AJ, Feldman L. An erythropoietin autocrine/paracrine axis modulates the growth and survival of human prostate cancer cells. Mol Cancer Res 2009;7(7):1150-7.

[6] Shi Z, Hodges VM, Dunlop EA, Percy MJ, Maxwell AP, El-Tanani M, et al. Erythropoietin-induced activation of the JAK2/STAT5, PI3K/Akt, and Ras/ERK pathways promotes malignant cell behavior in a modified breast cancer cell line. Mol Cancer Res 2010;8(4):615-26.

[7] Beleslin-Cokic BB, Cokic VP, Yu X, Weksler BB, Schechter AN, Noguchi CT. Erythropoietin and hypoxia stimulate erythropoietin receptor and nitric oxide production by endothelial cells. Blood 2004;104(7):2073-80.
[8] Mihov D, Vogel J, Gassmann M, Bogdanova A. Erythropoietin activates nitric oxide synthase in murine erythrocytes. Am J Physiol Cell Physiol 2009;297(2):C378-88.

[9] Azarov I, He X, Jeffers A, Basu S, Ucer B, Hantgan RR, et al. Rate of nitric oxide scavenging by hemoglobin bound to haptoglobin. Nitric oxide 2008;18(4):296-302.

[10] Manalo DJ, Buehler PW, Baek JH, Butt O, D’Agnillo F, Alayash AI. Acellular haemoglobin attenuates hypoxia-inducible factor-1alpha (HIF-1alpha) and its target genes in haemodiluted rats. Biochem J 2008;414(3):461-9.

[11] Westenbrink BD, Lipsic E, Van der Meer P, Van der Harst P, Oeseburg H, Du Marchie Sarvaas GJ, et al. Erythropoietin improves cardiac function through endothelial progenitor cell and vascular endothelial growth factor mediated neovascularization. Eur Heart J 2007;28(16):2018-27.

[12] Westenbrink BD, Ruifrok WP, Voors AA, Tilton RG, van Veldhuisen DJ, Schoemaker RG, et al. Vascular endothelial growth factor is crucial for erythropoietin-induced improvement of cardiac function in heart failure. Cardiovasc Res 2010;87(1):30-9

[13] Santhanam AV, Smith LA, Akiyama M, Rosales AG, Bailey KR, Katusic ZS. Role of endothelial NO synthase phosphorylation in cerebrovascular protective effect of recombinant erythropoietin during subarachnoid hemorrhage-induced cerebral vasospasm. Stroke 2005;36(12):2731-7.

[14] Satoh K, Kagaya Y, Nakano M, Ito Y, Ohta J, Tada H, et al. Important role of endogenous erythropoietin system in recruitment of endothelial progenitor cells in hypoxia-induced pulmonary hypertension in mice. Circulation 2006;113(11):1442-50.

[15] Yu AY, Frid MG, Shimoda LA, Wiener CM, Stenmark K, Semenza GL. Temporal, spatial, and oxygen-regulated expression of hypoxia-inducible factor-1 in the lung. Am J Physiol Lung Cell Mol Physiol 1998;275(4):L818-26.

[16] Ward JP, McMurtry IF. Mechanisms of hypoxic pulmonary vasoconstriction and their roles in pulmonary hypertension: new findings for an old problem. Curr Opin Pharmacol 2009;9(3):287-96.

[17] Rairigh RL, Le Cras TD, Ivy DD, Kinsella JP, Richter G, Horan MP, et al. Role of inducible nitric oxide synthase in regulation of pulmonary vascular tone in the late gestation ovine fetus. J Clin Invest 1998;101(1):15-21.

[18] Rairigh RL, Storme L, Parker TA, Le Cras TD, Markham N, Jakkula M, et al. Role of neuronal nitric oxide synthase in regulation of vascular and ductus arteriosus tone in the ovine fetus. Am J Physiol Lung Cell Mol Physiol 2000;278(1):L105-10.

[19] Le Cras TD, Xue C, Rengasamy A, Johns RA. Chronic hypoxia upregulates endothelial and inducible NO synthase gene and protein expression in rat lung. Am J Physiol Lung Cell Mol Physiol 1996;270(1):L164-70.

[20] Fagan KA, Tyler RC, Sato K, Fouty BW, Morris KG, Huang Jr PL, et al RodmanDM. Relative contributions of endothelial, inducible, and neuronal NOS to tone in the murine pulmonary circulation. Am J Physiol Lung Cell Mol Physiol 1999;277(3):472-8.

[21] Shaul PW. Ontogeny of nitric oxide in the pulmonary circulation. Semin Perinatol 1997;21(5):381-92.

[22] Ignarro LJ, Byrns RE, Buga GM, Wood KS. Endothelium-derived relaxing factor from pulmonary artery and vein possesses pharmacologic and chemical properties identical to to those of nitric oxide radical. Circ Res 1987;61:866-79.

[23] Gilchrist M, Shore AC, Benjamin N. Inorganic nitrate and nitrite and control of blood pressure. Cardiovasc Res 2010;89(3):492-8.

[24] Yang F, Troncy E, Francoeur M, Vinet B, Vinay P, Czaika G, et al. Effects of reducing reagents and temperature on conversion of nitrite and nitrate to nitric oxide and detection of NO by chemiluminescence. Clin Chem 1997;43(4):657-62.

[25] Dias-Junior CA, Cau SB, Tanus-Santos JE. Role of nitric oxide in the control of the pulmonary circulation: physiological, pathophysiological, and therapeutic implications. J Bras Pneumol 2008;34(6):412-9.

[26] Ricciardolo FL, Sterk PJ, Gaston B, Folkerts G. Nitric oxide in health and disease of the respiratory system. Physiol Rev 2004;84(3):731-65.

[27] Chin K, Oda N, Shen K, Noguchi CT. Regulation of transcription of the human erythropoietin receptor gene by proteins binding to GATA-1 and Sp1 motifs. Nucleic Acids Res 1995;23(15):3041-9.

[28] Ogilvie M, Yu X, Nicolas-Metral V, Pulido SM, Liu C, Ruegg UT, et al. Erythropoietin stimulates proliferation and interferes with differentiation of myoblasts. J Biol Chem 2000;275(50):39754-61.

[29] Yu X, Shacka JJ, Eells JB, Suarez-Quian C, Przygodzki RM, Beleslin-Cokic B, et al Erythropoietin receptor signaling is required for normal brain development. Development 2002;129(2):505-16.

[30] Chen ZY, Wang L, Asavaritkrai P, Noguchi CT. Up-regulation of erythropoietin receptor by nitric oxide mediates hypoxia preconditioning. J Neurosci Res 2010;88(14):3180-8.

[31] Walker BR, Resta TC, Nelin LD. Nitric oxide-dependent pulmonary vasodilatation in polycythemic rats. Am J Physiol Heart Circ Physiol 2000;279(5):H2382-9.

[32] Fried R, Meyrick B, Rabinovitch M, Reid L. Polycythemia and the acute hypoxic response in awake rats following chronic hypoxia. J Appl Physio 1983;55(4):1167-72.

[33] Hasegawa J, Wagner KF, Karp D, Li D, Shibata J, Heringlake M, et al. Altered pulmonary vascular reactivity in mice with excessive erythrocytosis. Am J Respir Crit Care Med 2004;169(7):829-35.

[34] Su CF, Yang FL, Chen HI. Inhibition of inducible nitric oxide synthase attenuates acute endotoxin-induced lung injury in rats. Clin Exp Pharmaco Physiol 2007;34(4):339-46. 
[35] Sittipunt C, Steinberg KP, Ruzinski JT, Myles C, Zhu S, Goodman RB, et al. Nitric oxide and nitrotyrosine in the lungs of patients with acute respiratory distress syndrome. Am J Respir Crit Care Med 2001;163(2):503-10.

[36] Pautz A, Art J, Hahn S, Nowag S, Voss C, Kleinert H. Regulation of the expression of inducible nitric oxide synthase. Nitric oxide 2010;23(2):75-93.
[37] Hampl V, Bíbová J, Banasová A, Uhlík J, Miková D, Hnilicková O, et al. Pulmonary vascular iNOS induction participates in the onset of chronic hypoxic pulmonary hypertension. Am J Physiol Lung Cell Mol Physiol 2006;290(1):L11-20. 